\title{
The Leprosy Colony, Uzuakoli, S. Nigeria.
}

Second Annual Report, March 31st, 1934.

J. A. K. BRown.

$\mathrm{O}$ $\mathrm{N}$ the 31st March, 1933, the number of patients in residence was three hundred and ninety. At the time of writing this, the second Annual Report, there are four.hundred and thirty-six inmates of the Colony, showing a net increase during the year of forty-six in-patients. Taking into account those, who for various reasons have left the Colony and those who have died, a total of five hundred and forty-six cases have had treatment as in-patients, whilst a further two hundred have received treatment as out-patients once a week with an average attendance of approximately one hundred and twenty. The actual figures showing the record of the various Divisions in the Owerri Province are in Table I, as follows :-

\begin{tabular}{|c|c|c|c|c|c|c|c|c|c|c|c|}
\hline $\begin{array}{l}\text { Okigwe } \\
\text { Owerri } \\
\text { Bende } \\
\text { Ahoada } \\
\text { Aba } \\
\text { Others }\end{array}$ & $\begin{array}{c}1933 \\
148 \\
57 \\
131 \\
26 \\
12 \\
16\end{array}$ & $\begin{array}{c}\text { Admis- } \\
\text { sions } \\
26 \\
93 \\
10 \\
18 \\
9 \\
-\end{array}$ & $\begin{array}{l}\text { Total c } \\
174 \\
150 \\
141 \\
44 \\
21 \\
16\end{array}$ & $\begin{array}{c}\text { Dis- I } \\
\text { harges } \\
4 \\
2 \\
7 \\
\frac{1}{2}\end{array}$ & $\begin{array}{c}\text { Dismis- } \\
\text { sals } \\
4 \\
6 \\
10 \\
1 \\
-\end{array}$ & $\begin{array}{c}\text { Left } \\
7 \\
10 \\
6 \\
10 \\
-3\end{array}$ & $\begin{array}{c}\text { Deaths } \\
9 \\
19 \\
6 \\
2 \\
1 \\
-\end{array}$ & $\begin{array}{l}1934 \\
150 \\
118 \\
112 \\
80 \\
20 \\
11\end{array}$ & $\begin{array}{c}\text { Adults } \\
127 \\
102 \\
74 \\
27 \\
19 \\
10\end{array}$ & $\begin{array}{c}\text { Chil- } \\
\text { dren } \\
23 \\
11 \\
38 \\
3 \\
1 \\
1\end{array}$ & $\begin{array}{r}\text { Total } \\
150 \\
113 \\
112 \\
30 \\
20 \\
11\end{array}$ \\
\hline Tota & 390 & 156 & 546 & 16 & 21 & 36 & 37 & 436 & 359 & 77 & 486 \\
\hline
\end{tabular}

Table II shows the numbers of those who are independent, partly dependent and wholly dependent. Those classed as " independent" subsist themselves, by trading in the Colony or by obtaining assistance from home. Those "partly dependent" receive half subsistence from the colony. Those " dependent" are subsisted entirely at the expense of the colony funds, being paid in money or kind for work done, the work being the maintenance and development of the colony. A distinction has been made between adults and children, as the cost of subsistence of a child is less than for an adult.

\begin{tabular}{|c|c|c|c|c|c|c|c|}
\hline \multirow{7}{*}{$\begin{array}{l}\text { Okigwe } \\
\text { Owerri } \\
\text { Bende } \\
\text { Ahoada } \\
\text { Aba } \\
\text { Others }\end{array}$} & \multirow{7}{*}{$\begin{array}{l}\cdots \\
\cdots \\
\cdots \\
\cdots \\
\cdots \\
\cdots\end{array}$} & \multicolumn{5}{|c|}{$\begin{array}{c}\text { TABLE II. } \\
\text { Partly }\end{array}$} & Total \\
\hline & & Adults. & Children. & Adults. & Adults. & Children. & \\
\hline & & 1 & - & 二 & 101 & $\begin{array}{l}21 \\
11\end{array}$ & 113 \\
\hline & & 37 & 27 & 18 & 19 & 11 & 112 \\
\hline & & - & - & - & 27 & 3 & 30 \\
\hline & & - & - & - & 19 & 1 & 20 \\
\hline & & 1 & - & - & 9 & 1 & 11 \\
\hline & & 42 & 29 & 18 & 299 & 48 & 436 \\
\hline
\end{tabular}


Table III shows the numbers of men, women and children included in the total resident on March 31st, 1934, of four hundred and thirty-six, together with their classification. TABLE III.

$\begin{array}{llccccc} & & & \text { Men. } & \text { Women. } & \text { Children. } & \text { Total. } \\ \text { Early Cases } & \ldots & \ldots & 24 & 13 & 28 & 65 \\ \text { Late Cases (able-bodied) } & \ldots & \ldots & 149 & 56 & 30 & 235 \\ \text { Advanced Cases (disabled) } & \ldots & \mathbf{8 8} & 29 & 19 & 136 \\ & & & \overline{261} & \overline{98} & \overline{77} & \overline{436}\end{array}$

Of the thirty-seven deaths, twenty-eight took place in the first half of the year. Eighteen of them were among a group of patients in a very advanced stage of the disease on admission, and not really suitable cases for a treatment centre. The causes of death were principally intercurrent diseases, such as pneumonia, dysentery, and chronic nephritis, whilst in one case in a patient making good progress, death was sudden and due to cerebral hæmorrhage.

Of those admitted, thirty-six have left. The larger proportion of these were patients who did not stay long enough to find out whether they would like the settlement or not. Four of these left the same day that they arrived, others stayed less than one month. Of the remainder some had permission to return to their homes for a holiday, as they were feeling better, and as their health has apparently continued, they have not seen any reason to return. Others have been called to their homes by some domestic trouble, and it has been reported that their condition has been made worse by the long journey, and they have not been able to make the return journey. A few cases left when they were allotted a piece of land to farm to provide their means of subsistence, preferring to do the regular development work of the colony for a weekly remuneration.

It is with a sense of satisfaction that sixteen cases are reported discharged. Eleven of these were cases of nerve leprosy, the other five having involvement of both nerves and skin. They were all discharged as uninfectious, or, as recommended by the International Conference of 1931, held at Manila, "closed cases," there being no bacilli detectable on examination. Three of the sixteen discharged were classed as " arrested cases," having shown no signs of activity for a period of between one and two years. The other thirteen were described as " quiescent," having shown no activity for at least three months. All were recommended to report periodically for re-examination. It would be a mistake to suggest that these cases are cured; they have been rendered, as far as is ascertainable, uninfectious to 
other people, and free from all symptoms. If they can maintain their bodily resistances at a high level, they may proceed to permanent arrest of the disease; the natural tendency, however, after leaving the settlement is to revert to the habits and conditions in which the disease first made its attack.

The treatment adopted has been similar to that reported previously, namely, the eradication as far as possible of co-existing diseases, followed by carefully controlled injections of alepol or a $50 \%$ mixture of hydnocarpus oil and its ethyl ester. The injections have been intramuscular, but in a number of cases with a limited number of patches, iodised moogrol has been injected intradermally. Half the dose of alepol that could be tolerated without a reaction has been given intramuscularly, the balance of the dose being given with iodised moogrol intradermally.

A few cases were given intravenous injections of mercurochrome. There was swelling and bursting of some of the nodules in two cases. Two of the patients thought that their general condition was better, and their sedimentation index was improved. In the other cases there was no marked improvement.

An attempt has also been made to evaluate the addition of the vitamin B complex, in concentrated form, to the diet of some of the inmates. The absence of this vitamin results in beri-beri and polyneuritis, dermatitis, pellagra and deficient development, the sequel depending on the relative or absolute deficiency of different components of the complex together with other factors. The mycobacterium leprae resists attempt to culture and inoculate it successfully, and it is recognised that leprosy develops only in those with some defect in their natural resistances. It seemed reasonable to ask whether the development of leprosy in the human body might depend upon a partial deficiency of some component of the vitamin B complex, or on the other hand whether such a partial deficiency among other factors, might predispose considerably to the invasion of leprosy.

The work done in the settlement so far consists of inquiries into the ordinary diets of the patients prior to admission. Different groups have then had daily administrations of vitamin B in concentrated form, and comparisons made with control groups. Fifty children were chosen first, this being the commonest age of onset, and as at this age the body needs all its reserves for growth and development. A second group consisted of twenty-five male adult cases free from complications of the disease. 
Observations have been kept over a period of nine months, and if results justify it, a special report may be issued later. Opportunity is taken here, however, of remarking that from the enquiries made it was apparent that many of the cases had been accustomed to an excessive carbohydrate dietery, including protein low in quality and biological value, with fluctuating and sub-minimal quantities of both vitamins $\mathrm{B}$ and $\mathrm{C}$, and that in some of the cases to whom vitamin $B$ was administered, there was a definite general bodily response.

The uninfected children of the inmates have now been separated from their parents, and are housed in a cement block Babies House provided by the Nigerian Branch of the British Empire Leprosy Relief Association. Originally there were about twenty such children, but some of these have been returned to their homes to the care of relations. At the present time, however, there are six children being fed artificially, in the charge of clean nurses, and it is hoped that this will prevent these children contracting leprosy.

The principal work in the colony has been its continual development. Much ground has been rooted to provide more town space, and other ground has been prepared for an oil palm plantation. The farms were on a communal basis, and the yields were in keeping with the average in the district. The new farms are partly communal and partly individual. About eighty patients have been given a piece of land and seed yams, with the hope that after the harvest they will be able to subsist themselves. Until the harvest they are working part of the week for the colony, and receiving a remuneration accordingly. It was found that a large number of the cases were not well enough to become independent farmers; whilst some that were well enough preferred regular hours doing colony work, with regular remuneration, and at first were obstinate with regard to the change.

In addition, everybody in the colony has been given a small plot of ground in which to grow a few extra vegetables.

The social, recreational and religious work in the colony has been provided for financially by the Methodist Missionary Society. Clothing and blankets have been provided for the poor, and work in the school, the Boy Scouts and the band has been maintained. Presents were given to all the patients at Christmas, and prizes to the winners of the Annual Sports on Boxing Day. 
A number of visits have been paid during the year. It was gratifying to have visits from parties of Chiefs under the guidance of the respective District Officers of the Ahoada and Owerri Divisions. The colony has been especially honoured by visits of His Excellency the Governor of Nigeria and Lady Cameron, His Honour the Acting Lieut.Governor of the Southern Provinces, The Director of Medical Services of Nigeria, and the Residents of the Owerri Province. 